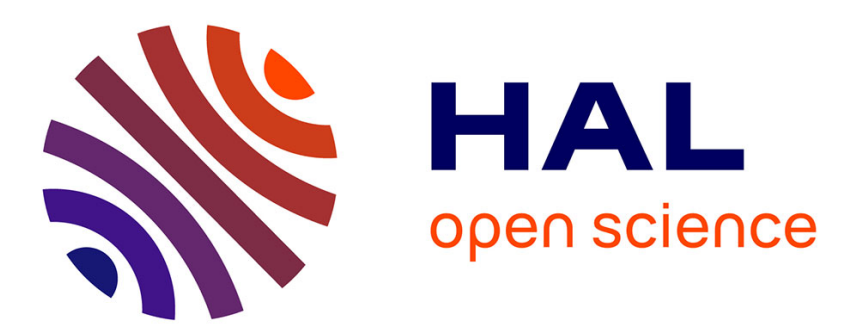

\title{
Who governs Europe? Public versus private regulation of the sustainability of fish feeds \\ Caitriona Carter
}

\section{To cite this version:}

Caitriona Carter. Who governs Europe? Public versus private regulation of the sustainability of fish feeds. Journal of European Integration / Revue d'Intégration Européenne, 2015, 37 (3), pp.335-352. 10.1080/07036337.2014.968566 . hal-01118693

\section{HAL Id: hal-01118693 \\ https://hal.science/hal-01118693}

Submitted on 19 Feb 2015

HAL is a multi-disciplinary open access archive for the deposit and dissemination of scientific research documents, whether they are published or not. The documents may come from teaching and research institutions in France or abroad, or from public or private research centers.
L'archive ouverte pluridisciplinaire HAL, est destinée au dépôt et à la diffusion de documents scientifiques de niveau recherche, publiés ou non, émanant des établissements d'enseignement et de recherche français ou étrangers, des laboratoires publics ou privés. 


\title{
Who governs Europe?
}

\section{Public versus private regulation of sustainability of fish feeds}

\section{Caitríona Carter}

\begin{abstract}
:
Primary tensions within EU government are consistently shown as between public actors who compete with one another to set policy ${ }^{-}$the European Commission/Member States/European Parliament. Whilst important, such a wholehearted focus on these conflicts is obscuring other tensions increasingly defining its politics, namely between public versus private regulation. These merit greater attention in European integration analysis. Private regulation is not totally disconnected from its public counterpart: through standardization, private actors can evoke and institutionalize EU norms and principles, like sustainability, thus governing in its name; the contents of private self-regulation can potentially undermine the effects of EU public policies. To better capture the causes of these emerging public-private interdependencies and their consequences for EU government, a key contribution of this article is to argue for the necessity to both localize and particularize the inquiry on private regulation. This we demonstrate through presenting the revealing case of fishfeeds and their sustainability.
\end{abstract}

KEY WORDS: Interdependence; public and private regulation; standardization; sustainable development; European Union; fish feeds.

\section{INTRODUCTION}

Research in European Union (EU) studies has been dominated by disputes over competing images of Europe ${ }^{-}$e.g., :supranational `, :intergovernmental`, :multi-level` (Carter et al. 2015 
Author-produced version of the article published in Journal of european integration, 2015, 37(3), 335-352

forthcoming). Textbooks and academic articles alike continue to lay emphasis on characterising its sui generis nature and its hybrid supranational and intergovernmental features as the starting point for understanding its politics (Nugent 2010, p493; Ginsberg 2007, p1; Beyers and Diericks 1998). In these accounts, primary tensions in EU government are consistently shown as between public actors who compete with one another to set policy; either between the European Commission, Member State (MS) governments and the European Parliament (EP) (Scicluna 2012) or between the :EU` and the :nation state ${ }^{\smile}$, also represented by public actors (Young and Peterson 2006). Overall, the implied meaning of the government of the EU is the action of public organisations and this in a delimited set of arenas:

:[there are] a great variety of venues within the EU: the Commission, the EP, the European Council, the Council of Ministers and within each of these institutions different DGs, committees, Council configurations and the like (Lelieveldt and Princen 2011, p223).

A central point of this piece is to argue that such a wholehearted focus on conflicts between and within EU public actors as emblematic of the EU is obscuring other tensions which are increasingly defining its politics. More specifically, these are tensions between public policymaking on the one hand, versus voluntary private self-regulation on the other.

Of course, the role of private collective actors in the European integration process has been extensively studied (Marks and McAdam 1996; Richardson 1996; Peterson 1995). However, scholars have chiefly aimed to demonstrate private actors ` influence and engagement in public policymaking. This article considers a different type of activity of private actors, namely their voluntary and autonomous collective action to set private standards. Indeed, the current form of liberal capitalism in Europe and its Union is one where increasingly policy 
Author-produced version of the article published in Journal of european integration, 2015, 37(3), 335-352

The original publication is available at http://www.tandfonline.com/

doi : $10.1080 / 07036337.2014 .968566$

choices are not being taken by public actors acting together and in consultation with stakeholders, but by private collective actors acting :voluntarily ${ }^{-}$to self-regulate their own practices (Djama et al. 2011; Ponte et al. 2011; Fulponi 2006). This matters because private regulation is not totally disconnected from its public counterpart (Havinga 2006). Rather, private actors can evoke, and institutionalize, EU norms and principles in their standardsetting, thus governing in its name. Further, the contents of private standards can potentially undermine the effects of EU public policies. Public/private interdependencies thus merit greater attention in European integration analyses than they have been given hitherto.

In the literature, the emergence of this private self-government in Europe is attributed to larger processes of transformation. Yet, authors differ over both causes and consequences. Some refer to a :depoliticization of politics `(Hay 2007); others to changing relations between state and market (LeGalès and Scott 2008); others to the shortcomings of the state as a global regulator (Cafaggi 2010); others still to the emergence of the :stateless state (Bevir and Rhodes 2010). EU political programmes of simplification, ecological modernization and the knowledge based bio-economy (Birch et al. 2010) are claimed to encourage this trend. Yet, as our case study will show, staying at the global level of analysis to explain shifting power relations can be a limiting exercise. By contrast, a key contribution of this article is to argue for the necessity to both localize and particularize the inquiry on private regulation.

We demonstrate this here through presenting the revealing case of fishfeeds and their sustainability. Although fishfeeds might appear marginal to our understanding of the EU and how it works - a technical issue for a specialized literature on animal nutrition - in reality the politics of their European government crystallizes paradoxes of public/private interdependencies. First, the European Commission recently decided not to propose sustainability standards for feed ingredients, citing its trading obligations under WTO rules as a justification ${ }^{-}$and this in a context where the EU has consistently endorsed a programme of 
sustainable development and where sustainability of feeds has been a global issue since early 2000s. Nevertheless, in the absence of public rules, private actors have taken up a governing stance and set their own sustainability standards for EU produced salmon. Second, EU MSs, supported by the Commission, have chosen to re-authorize the use of processed animal proteins from poultry and pigs in fishfeeds and this in the name of sustainability. Yet, private standards already in place prevent the uptake of these ingredients, whereby firms claim to act as protectors of public interests undermining EU policies. In both cases, public and private

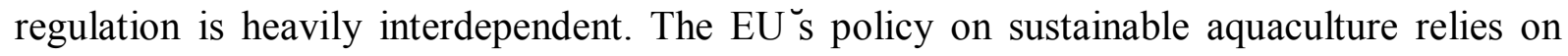
private standards to be effective; private standards in turn depend on EU environmental rules. Public versus private action is therefore simultaneously conflictual and mutually reinforcing and merits further investigation.

To pursue these points, we proceed as follows. First, we elaborate upon our conceptual starting point and approach to argue that accepting private self-regulation as part of European government requires shifting our understandings about that government. Second, we review the EU government of sustainability in feeds through analysing initiatives by EU public actors to govern this on an EU-wide scale. Rather than stopping our analysis there, however, we proceed in a third part to examine key regulatory work taking place alongside public developments and amongst private actors (supermarkets, feed companies, fish farmers and environmental NGOs). ${ }^{1}$ We conclude by revisiting the paradoxes of public versus private regulatory action in this EU government.

\footnotetext{
${ }^{1}$ The article is based on research carried out within a collective project funded by the French : Agence National de la Recherche (ANR) :The European Government of Industry (Co-ordinators Bernard Jullien and Andy Smith; 2009-2012). Research methods for investigating European aquaculture included documentary and statistical analysis, situated observation of practitioner meetings, and over 60 semi-structured elite interviews conducted in Scotland, France, Greece and Brussels with actors from a range of public bodies, collective private interest groups and individual firms along the feed and food chain (feed manufacturers, fish farmers, processors, retailers, e-NGOs).
} 


\section{WHO GOVERNS EUROPE AND ITS UNION? RECONCEPTUALIZING THE GOVERNMENT OF THE EU}

As alluded to above, a stock response to the question : who governs the EU? “would be to say the European Commission or $\mathrm{MSs}$ national governments - :the Commission, the

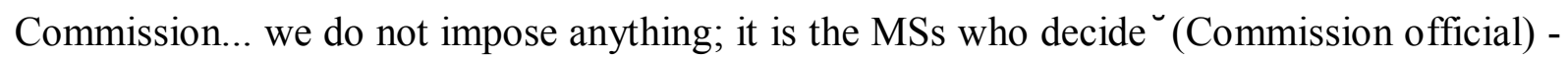
or some combination of Commission, Council, EP co-decision making (Lelieveldt and Princen 2011). Beyond this, scholars would give credence to policy networks, regional governments and other stakeholders, all of whom have been studied as shaping its public policies (Robert 2010; Carter and Smith 2008; De Maillard 2001; Jeffrey 2000). However, to accept voluntary private regulation as an element of EU government, we contend, requires that we re-think our understanding of :the government of the EU $ّ$ For, the majority of EU studies $`$ textbooks and articles would assume :EU government ${ }^{\complement}$ to be the work of EU public actors and instruments. Consequently, to move beyond this, we must draw upon a scholarship which has either challenged formalistic accounts of governing in general (Bevir 2011; Bevir and Rhodes 2008), or has sought to encourage new approaches to our understanding of the EU (Jullien and Smith 2014; Mangenot and Rowell 2010; Smith 2010; Favell and Guiraudon 2009: Fligstein 2008; Rumford 2002). This is an extensive literature grounded in a constructivist institutionalist or interpretivist ontology, but one rarely mobilized within EU studies $^{2}$.

A first demand made by this literature is that we change our understanding of :government ${ }^{\smile}$ and move away from formalistic conceptions (Bevir 2011, p193). Instead, scholars have proposed thinking about European government not as a particular body, but as a range of meaningful regulatory practices and interactions, instruments and ideas which make up the

\footnotetext{
${ }^{2}$ And frequently ignored in standard text books, even recent ones. For example, : After reading this chapter you will have found out that there are two major approaches to studying the $\mathrm{EU}^{\sim}$ [neofunctionalism and intergovernmentalism] (Lelieveldt and Princen, 2011:32).
} 
EU (Fligstein 2008). These governing practices need not be confined to certain :venues `nor involve certain groups of actors. Rather, this Europe is :made in particular spaces and through specific actor struggles, whose interconnections are often ill-defined (Carter et al. 2015 forthcoming). Thinking in this way means that we let go of thinking about the EU first and foremost as an object ${ }^{-}$a supranational Europe, a federal Europe in the making; an intergovernmental Europe. Instead, we re-define the EU as :a space of action [both real and imagined], which exists only to the extent that Europeans and others act in and on it ${ }^{\longleftarrow}$ (Carter et al. 2015 forthcoming).

From this decentred starting point, we can identify actor struggles during which Europe is given meaning (and built) and spaces of action in which these interactions take place ${ }^{-}$and this rather than commencing our analysis from any preconceived idea either about where these spaces might be or who might inhabit them. To do this here, we apply tools of :problematization ` (Jullien and Smith 2014; Svea 2010; Rochefort and Cobb 1994) and :instrumentation `(Smith 2013; Lascoumes and LeGalès 2007) to locate both where problems are being interpreted and where institutions are being set in the name of Europe. Problematization refers to the social construction of local conditions, such as choices of feed ingredients, as public or private (sectoral) problems to be resolved. This includes giving them social meaning (e.g. safe, organic, sustainable). For problematization to be effective, instrumentation must occur whereby compromises over interpretations of the problem and its solution are codified in policy instruments (Jullien and Smith 2014). We ask : who is defining

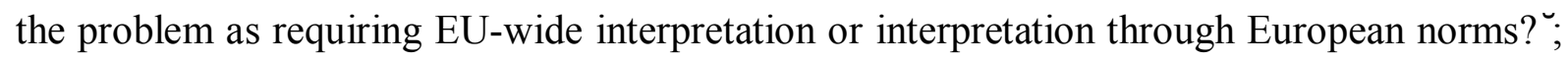

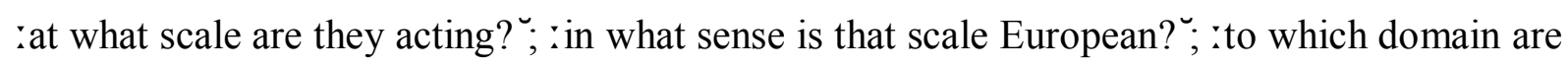
they assigning the problem - public or private? ${ }^{-}$; who continues to own the problem in instrumentation?` (Gilbert and Henry 2012). Critically, in these political contests, actors might be unaware either of the contribution they are making to Europe $\breve{s}$ creation (albeit 
political, economic, cultural - Lawn 2006, p280) or of the contribution which others are making. Yet, in neither case does this render their action irrelevant to our analysis.

In this manner, our decentred approach enables us to capture the role of private government in European regulation. The starting point for discerning EU government is no longer an essentialist assumption about its very nature and its key actors. Rather, it is the identification of mechanisms of problematization and instrumentation when they occur in its name. Both :traditional ${ }^{\sim}$ spaces of EU public policymaking as well as private business to business contracts can be seized as sites for European politics and studied in their own right. European government is accordingly reformulated as meaning problematization and instrumentation through public regulation on an EU-wide scale and through private regulation in European markets and in the name of Europe.

To demonstrate this further, we first analyse the European government of the sustainability of fishfeeds as meaning the social construction of problems and instruments in EU public regulation on this very issue, before going on to compare this work with its private counterpart.

\section{FROM SAFETY TO SUSTAINABILITY? EU PUBLIC ACTION IN FISHFEEDS}

Feeds are essential for certain types of aquaculture production ${ }^{-}$namely, finfish and prawns ${ }^{-}$ and can represent half of all production costs. Typical diets for carnivorous fish include fishmeal; fishoil; cereal sources; vegetable proteins, e.g., soya; vitamins; minerals; feed additives. Initially, feeds were not interpreted as a collective European problem: :nobody really knew what should go in the feed ${ }^{\smile}$ (producer representative). Over time, this situation has radically altered. Today, under EU food safety regulation, choices of feed ingredients must respect principles of human health, animal health and environmental impact and are subject to authorisation by the European Food Safety Authority (EFSA). Feed ingredients 
have therefore been problematized and regulated on grounds of safety. But, have they equally been problematized on grounds of sustainability?

\section{DG MARE, external consultation and an EP inquiry: sustainability as a :politics of substitution $\asymp$ and no instrumentation}

In 2007, the Commission launched an EU-wide consultation to renew its strategy for the :Sustainable Development of European Aquaculture - the farming of fish, shellfish and aquatic plants (Carter and Cazals 2014). Aquaculture had grown rapidly as an industrialized farming activity in Europe throughout the 1980-90s, yet by the mid-2000s its growth had slowed overall and was in decline for some species (Commission 2009a). The objective of the consultation process was to identify obstacles to sustainable growth.

The question of feeds was put directly on the agenda by the Commission. To be clear, the

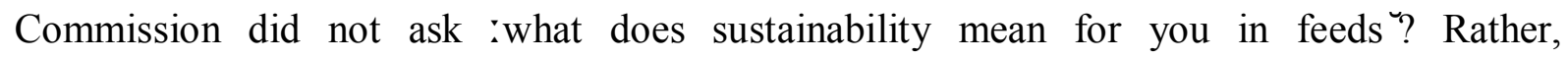
stakeholders were asked to what extent fishmeal and fishoil used in feeds represented :limiting factors $`$ to growth. The content of this question had its root in negative assessments of the availability of these ingredients sourced from fisheries in Peru, Chile and the NE Atlantic (Commission 2002). Assuming an expected rise in demand for these products on global markets due to increasing aquaculture growth worldwide, the Commission sought to question whether future European growth would in turn be limited by supply. This mattered because these marine resources are vital components of fish diets. Not only does fishmeal contain essential proteins for fish growth, fishoil contains long chain fatty acids (Omega 3, 6) whose trace elements provide essential nutritional value of farmed fish for human mental health (Crawford 2010).

The majority of stakeholder responses did see fishmeal and fishoil as potentially limiting factors to growth. But they argued that this limitation would depend upon finding suitable 
alternatives. This was already happening in practice. Whereas fifteen years ago fish diets had been composed of c75-85\% marine ingredients, by 2007 this had been reduced to c $20-25 \%$. More precisely, marine proteins and oils had been replaced by vegetable ones. But was this sufficient? The posing of the question in terms of growth encouraged discussions around price, whether there was a crisis or not concerning the supply (e.g. International Fishmeal and Fishoil Organisation) $)^{3}$ and on suitable replacements (e.g. Scottish Salmon Producers` Organisation).

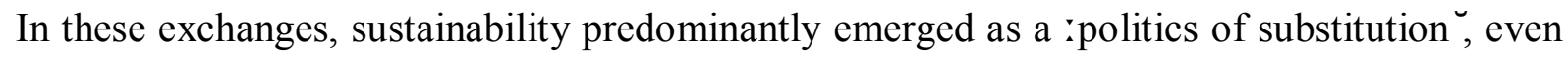
though other possible implications of feeds for the sustainable development of aquaculture were evoked by stakeholders. For example, in response to a question on environmental challenges, consumer awareness of potential negative environmental impacts of feed fisheries was highlighted as an issue related to the sustainability of feeds (e.g. Scottish Natural Heritage). However, this was not where the Commission would eventually place its own emphasis. Its strategy, published in 2009, took the issue of replacements as its focus (2009b p4.2.4). ${ }^{4}$ Whereas alternate definitions were therefore available, the politics of sustainability in feeds was primarily interpreted by the Commission as one of substitution.

Sustainability and feeds was taken up once more as an issue by the Economic and Social Committee, the Committee of the Regions, the EP Inter-Group on Climate, Change, Biodiversity and Sustainable Development (IG-CCBSD) and the EP PECH committee (interviews). The IG-CCBSD held a conference which put the question differently ${ }^{-}$:Can a growing aquaculture industry continue to use fishmeal and fishoil in feeds and remain sustainable? Starting with a focus on the meaning of sustainable aquaculture, participants stressed the link between this goal and maintaining sustainable feed fisheries. This was

\footnotetext{
${ }^{3}$ All contributions to the Commission 2009 consultation mentioned can be found at: $\mathrm{http} / /$ ec.europa.eu/dgs/maritimeaffairs_fisheries/consultations/aquaculture/contributions/index_en.htm

${ }^{4}$ The mention here of : standards ${ }^{4}$ was explained on interview as not intending to have any consequence.
} 
because aquaculture had been initially hailed as a sustainable alternative to collapsing fish stocks. However, if producers fed their fish on other fish captured in badly managed fisheries, this challenged this claim. Accordingly, fishmeal and fishoil should only be used for feeds if sourced from well-managed capture fisheries.

This shifted the debate away from questions of availability on to questions of how we manage the supply in the first case. Sustainability of feeds was re-articulated around environmental impacts of feed fisheries and stock management methods. The focus changed from a :politics of substitution $`$ to a :politics of provenance ${ }^{\swarrow}$ of raw materials. Further, interpreting sustainability of feeds in terms of provenance of raw materials, actors began to discuss the sustainability of other ingredients, not only marine resources. If sustainability meant ensuring responsibly resourced supplies, then this should also be the case for ingredients such as soya or palm oil.

Following these discussions, the EP report (Milana), published in 2010, made a general call to the Commission

:to ensure that the sourcing of raw materials used for fish feed follows an environmentally acceptable practice and does not have negative impacts on the ecosystems from which these ingredients are harvested $`(14)$.

Additionally, this report urged :the Commission to issue specific technical guidelines on the certification of sustainable fish feed (14). However, the Commission has not acted in response to either of these requests. In keeping with their analysis of the problem as one of substitution, they have instead reiterated their objective to facilitate EU market entry of replacement products (interviews). More fundamentally still, officials from different DGs (and Commissioner Damanaki) have argued against EU-wide regulatory solutions to the problem of provenance. Citing their responsibilities as they understand them under WTO 
trade rules, they have stated that on questions of trade and sustainability, :we cannot govern extra-territorially`(EC official).

In summary, when designing its strategy, sustainability in feeds was repeatedly interpreted by the Commission as a politics of substitution. Views gathered during consultation either confirmed this position or failed to persuade officials or the College otherwise. For although some actors did define this issue as a politics of provenance, no actors really pushed for instrumentation. MEPs clearly were concerned, yet were disadvantaged in part by their uncertainties over how to govern:

:we want sustainable aquaculture $\check{u}$. it $\breve{s}$ been very controversial and the question is still about what is sustainable? how do you define sustainability? what is technically

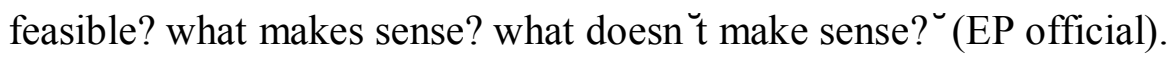

\section{DG SANCO, SCFCAH, EFSA: Fish, chickens, pigs and sustainability}

After these debates orchestrated by DG MARE which ultimately led to no reglementary action, the topic of fishfeeds connected with sustainable aquaculture fell off the public agenda of the EU. Then, in July, 2012, the Standing Committee of the Food Chain and Animal Health, (SCFCAH) took a decision which would once more raise the profile of fishfeeds in the public space. SCFCAH is a comitology committee composed of scientific experts representing the governments of the MSs, along with the Commission in its capacity as policy

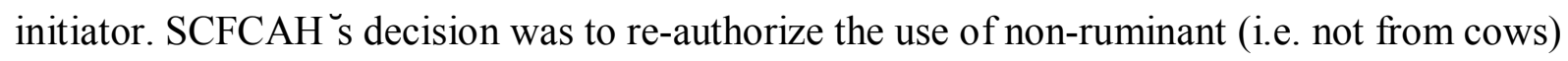
Processed Animal Proteins (PAPs) in fishfeeds. PAPs are derived from animal (poultry and pig) by-products and were banned for use in feeds in 2001 following food safety crises, including those linked to the Bovine Spongiform Encephalopathy (BSE) epidemic. PAPs are sourced from abattoir or catering waste of animals which have been certified as : fit for human consumption and are rendered products. The public reaction to this decision in some MSs 
was hostile, claiming it to be against nature :you have never seen a fish eat a pig `(José Bové cited by Mauriac, 2013). It was also a decision not supported by the French, German or UK governments ${ }^{-}$not on grounds of safety, which they did not dispute, but on grounds of social acceptability. Yet, one of the main interests which we have in this case is that it was legitimated not only in the name of food safety, but specifically through references to sustainability.

Initially, whether to re-authorize PAPs for fishfeeds was not posed as a question either by or for the aquaculture industry. Rather, it followed the collective action of the European fat renderers and processors ` industry, along with European feed manufacturers (interviews; Carter 2015, forthcoming). Within the European Commission, it was DG SANCO who led negotiations with the MSs, not DG MARE as with the aquaculture strategy. The key value over which the re-authorisation was articulated was that of food safety - although industry representatives also talked up the positive economic consequences this decision would potentially have for European renderers (and feed companies), and hence for EU market growth. Commission officials in charge of the dossier in DG SANCO were those in charge of the BSE dossier with a responsibility to eradicate BSE. Safety was therefore uppermost in their minds. Having already received in 2007 a favourable scientific opinion from EFSA on the safety aspects of using PAPs in feeds, their overriding concern was to ensure the putting in place of a scientific test robust enough to be able to detect the presence of ruminant DNA (interviews). Beyond this, officials were keen to start lifting the ban by commencing with fishfeeds - a feed processing system largely disconnected from animal feeds and therefore easier to control for either contamination or cannibalism (interviews).

Yet, although safety was the central value around which the re-authorisation was articulated, it was not the only one. Beliefs in sustainability were also held by officials and within the

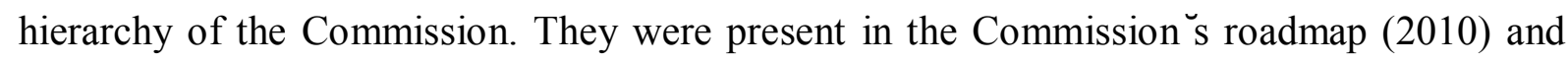


were at the forefront of press statements issued to announce the re-authorisation: :improve the overall sustainability of the sector ${ }^{`}$ (EC Press release 14.02.13). Renderers and feed manufacturing companies too had advanced sustainability arguments to justify reauthorisation, as did fish farmers we interviewed. According to these arguments, and as expressed by Commission officials, PAPs were sustainable by their very nature as they were renewables. Not only could they be used to replace fishmeal as a source of protein, thereby reducing pressures on wild fish stocks (politics of substitution), their use would valorize byproducts which would otherwise be wasted and thrown away. This equation of renewables with sustainability is consistent with a global narrative espoused by the European Commission in many policy documents on the knowledge-based bio-economy (Birch et al. 2010, p2899). Accordingly, :some natural resources are seen as inherently sustainable and/or eco-efficient because they are renewable (Birch et al. 2010, p2902). Government should be aimed at :the removal of 'barriers_ to the exploitation of renewable resources `and :provide an innovation-friendly market for its business ` (Birch et al. 2010, p2904). For the Commission, the re-authorisation of PAPs can therefore be analysed as an instrumentalization of sustainability in fishfeeds meaning easing market access for inherently sustainable products.

In summary, throughout 2007-2013, interpretations of sustainability in fishfeeds as a :politics of substitution ` dominated Commission practices and, through MS instrumentation, were

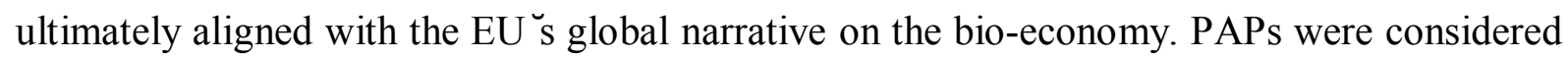
sustainable by their very nature as renewables and a sustainability test for choices of ingredients was not governed by EU rules. EU public actors either stated that they could not govern the provenance of ingredients or were impressed by uncertainties over how to do this. In short, they consistently claimed to be hampered in assuming any governing role in setting standards to certify sustainable fishfeed. 


\section{SUSTAINABILITY AS MEASURED, CODIFIED AND GOVERNED:} AUTONOMOUS COLLECTIVE PRIVATE ACTION FOR EU PRODUCED

\section{SALMON}

A study of problematization and instrumentation practices within traditional EU venues Commission consultation processes, EP groupings and committee inquiries, comitology reveals that whereas a politics of substitution is governed in the EU, a politics of provenance is not. EU public actor practices, however, represent only the :top of the iceberg (Fligstein 2008, p12), what : lies above water - its :visible part (Favell and Giraudon 2009, p551). Here, we go further in our analysis to consider other spaces of action where a European politics of provenance is both problematized and governed. More precisely, this is European government as collective private self-regulation in the name of Europe, setting sustainability standards for EU farmed salmon. For these actors, sustainability as a :politics of substitution is old news - a policy constantly worked upon through reductions of marine ingredients in feeds and investment in enhanced technical innovation (interviews). For them, sustainability

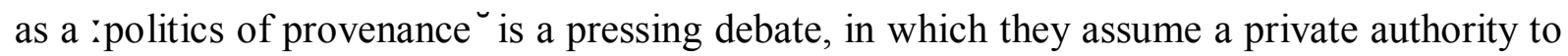
set standards giving meaning to sustainability.

Although the private government which we discuss here mainly involves private collective action of UK actors, including UK supermarkets, as well as both EU-wide and global actors, we consider it as also :European $`$ for many reasons. First, actors are institutionalizing EUwide norms of sustainability and traceability and acting as :owners of the problem ` (Gilbert and Henry 2012). Second, problematization over standards was facilitated through EU funding of a workshop on this very issue. Third, arguments in political economy argue that :the economy [should] no longer [be] defined uniquely by national borders, but by areas of activities for achieving financial and welfare objectives `(Fulponi 2006: 4). In our case, standards being set govern all 3 feed manufacturing companies `sourcing practices who 
provide feeds for $96 \%$ of Scottish feeds $(90 \%$ of EU salmon is farmed in Scotland; $10 \%$ in Ireland). Fourth, fishmeal and fishoil manufacturers $`$ responses to these demands have upgraded the sustainability of these products for all European finfish markets and not just for salmon. Instrumentation has therefore had knock-on effects across the EU ${ }^{-}$for example for French trout, where most companies will buy from certified sources, even if they have not set precise sourcing standards in contracts with supermarkets (interviews). For all these reasons, we conceptualize this as a space of action in which sustainable Europe is given meaning, is measured and governed.

\section{E-NGOs, feed companies and supermarkets: sustainability as a :politics of provenance}

Problematization of sustainability in fishfeeds as a :politics of provenance $\asymp$ can be traced back to the early 2000s. EU funded workshops, social movements `ampaign strategies and changes in private companies ${ }^{\leftrightharpoons}$ approaches to competitiveness can all be viewed as discursive starting points ascribing feeds this social meaning of sustainability.

Dialogue between global NGOs, feed companies supplying EU producers, biochemists and marine scientists was formalized and enriched within an EU-funded project workshop entitled

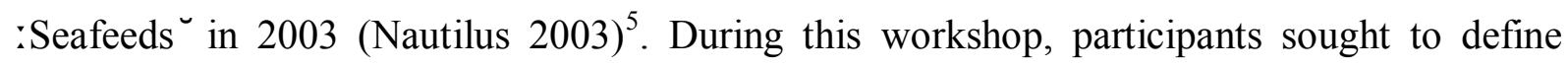
sustainability in feeds and to :establish appropriate sustainability criteria for labelling aquaculture feed ${ }^{\smile}$ (Nautilus 2003: 1). This included discussion over the :politics of provenance ${ }^{-}$of feeds and more precisely how to measure the sustainability of feed fisheries, i.e. which fisheries management methods were required to be in operation to claim sustainability of production. At the end, participants reported that

:there is nothing necessarily unsustainable about feeding fish-based feeds to fish, so

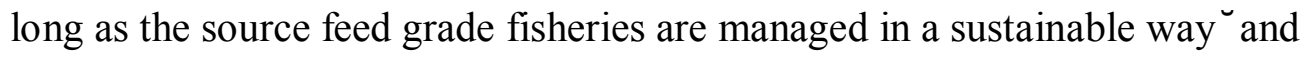

\footnotetext{
${ }^{5}$ EC Quality of Life and Management of Living Resources Programme (2002-2003)
} 
Author-produced version of the article published in Journal of european integration, 2015, 37(3), 335-352

:Although some sustainability criteria were agreed, corresponding standards were not. The setting of such standards will require a much more comprehensive and consultative process $`$ (Nautilus 2003, p5, p1).

At that time e-NGOs began to target private companies ${ }^{-}$fishfeed practices on grounds of sustainability and increase their aquaculture policy resources through the creation of new posts. New aquaculture officers took feeds as a central part of their work:

:we wanted to effect a change, so we looked across issues in aquaculture and where we could have the biggest effect $`(e-N G O$ policy officer).

Inter-NGO alliances were built which led, in one case, to the collective commissioning of specialist research by a fish biologist mounting a critique of measurement methods used by feed companies to judge the sustainability of salmon feed fisheries (Huntington 2004). Supermarkets were also targets. Using the media as a venue (Hughes et al. 2008, p350), Greenpeace attacked supermarkets seafood sourcing policies, first in the UK and then in other European countries, and ranked and shamed these policies against sustainability criteria developed by the Marine Stewardship Council (Greenpeace 2005, 2006).

Running parallel with these public campaigns, changes were on-going in the market place. Until 2002-2003, Scottish salmon companies had competed with imported Norwegian and Chilean salmon on a generic market. Market crashes in 2002-3 were interpreted by those companies still in business as the consequences of these strategies, saturating the market with a single commodity ${ }^{-}$salmon: : cheapest price and in direct competition with Norway ${ }^{-}$(feed company representative). Instead, it was argued that market differentiation was required, whereby along with an organic or a quality salmon, producers could farm and sell a salmon externally evaluated as :sustainable $\breve{:}$ :It is not simply, here is the contract, there is the price, this is the quality we want ${ }^{-}$(producer representative). Differentiation on grounds of 
sustainability thus brought into play the question of the provenance of raw materials used in fishfeeds.

For some supermarkets, too, strategies of competiveness were changing at this time : from competition based largely on price to one based on both price and quality attributes ` (Konefal et al. 2005, p292). Evoking arguments of :corporate social responsibility`and 'reputation (Fulponi 2006), companies sought, in the face of criticisms about potential negative impacts of fish farming, to guarantee to their customers that the salmon being sold in their shops had

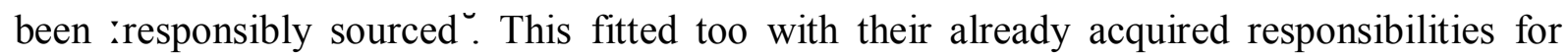
guaranteeing safety of their products. Scares over dioxin levels in EU salmon resulting from high profile publicity campaigns mediatizing (contested) scientific research on contaminants (conducted by Hites et al. 2004), revealed that 'none of the UK retailers could say we are ok in that we have a differentiated offer ${ }^{`}$ (supermarket seafood policy officer). This resulted in policy changes reducing sales contracts from :multiple sourcing, multiple origins ` to

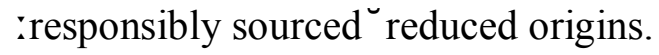

In summary, with the exception of the Seafeeds ${ }^{\circ}$ project work, where some participants wanted governments to apply their international commitments (Nautilus 2003), actor problematization in reports, company meetings and the media assigned the responsibility for instrumentation on provenance to private actors. Concerning e-NGO action, this echoed that undertaken in other industries - e.g. forestry and retail - namely to :shame the corporation rather than to :make demands on the state (Bartley and Child 2010, p3). Rather than work on public policy, e-NGOs worked instead on consumer behavior:

:there was an argument going on about whether we should be influencing through consumption or production ǔ [we are] working on consumption through work with retailers `(e-NGO representative). 
Author-produced version of the article published in Journal of european integration, 2015, 37(3), 335-352

The original publication is available at http://www.tandfonline.com/

doi : $10.1080 / 07036337.2014 .968566$

Additionally, private firms were conscious that they were acting within an EU framework which had transferred on them the responsibility for governing traceability of their product:

:Traceability is a requirement anyway but has evolved more in terms of knowledge and transparency as to what the fish is eating (feed company).

\section{Standard-setting: measuring and codifying the provenance of raw materials}

Instrumentation swiftly followed problematization, whereby along with considerations of environmental impacts of fish farms, the issue of the sourcing of raw ingredients for feeds was paramount. Feed companies, salmon producers, e-NGOs and supermarkets worked to set criteria to evaluate and measure a sustainable salmon.

Standards have been analyzed as :key functions of governing ` (Ponte et al. 2011, p1; Lascoumes and LeGalès 2007). They include :classification, categorization, exclusion and inclusion thresholds `(Ponte et al. 2011, p1). A variety of standards were set through a variety of processes. Of course, to classify and categorize, expertise was required, including in fisheries science and management. Initially, private companies such as supermarkets relied upon the expertise built up by e-NGOs on these very questions, as well as the expertise held by feed companies, and entered into partnership with these actors (interviews). Much of the early work in standard-setting therefore had multiple stakeholder input. In this process, compromises were reached, in particular over how to address lack of data on ecosystem impacts of stocks and yet still be able to rank a feed fishery as sustainable. In these cases,

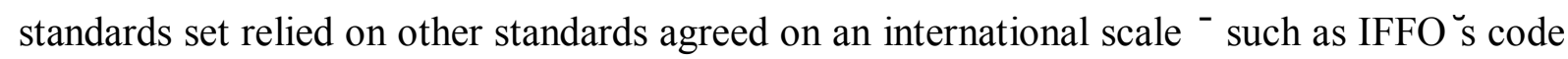
of responsible supply of fishmeal and fishoil. More recently, some supermarkets have begun to invest in expertise in-house and assert their authority over criteria. They have created new posts for marine biologists whose responsibility is to continue to design and work on classification systems to grade feed fisheries: 
Author-produced version of the article published in Journal of european integration, 2015, 37(3), 335-352

:We are always aware of what environmental NGOs are saying. But we have got our policies and we don $\breve{t}$ always agree. ... They have got their rating system: we have got

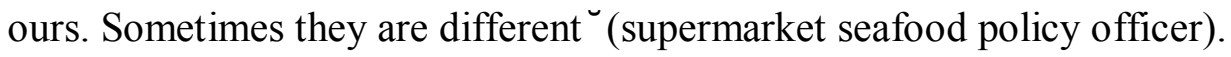

The process of standardization has thus been both in-house and in partnership. Some feed companies have established traffic light systems for stocks, only sourcing from those colourcoded :green . For some supermarkets, in order to judge whether a feed fishery is sustainable, company staff have sat down with private organizations like the Sustainable Fisheries Partnership, developed algorithms and systematically graded each fishery, drawing on publicly endorsed scientific assessments and knowledge about compliance with quotas. In other cases still, single partnerships have been formed with one feed company, one salmon producer and one supermarket to agree on sourcing choices which are then built into business to business contracts.

The overall extent of this standardization is such that according to some actors interviewed :being sustainable ${ }^{\complement}$ has become pre-competitive - a norm which must be respected to sell your product at home. Feed companies, supermarkets and producers mobilize their data to argue that e-NGOs can no longer claim their policies on sustainability to be meaningless: : we have a means of expressing sustainability (feed company; my emphasis). Further, governing the market through standardization has not been limited to a politics of provenance of marine resources. Indeed, companies have developed policies which prevent them from sourcing any feed ingredients, including soya, from unsustainable sources, and which must be sourced for example from companies who belong to the Roundtable on Responsible Soy Association. The

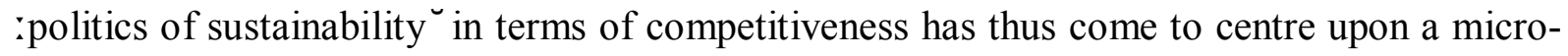
balancing of choices of ingredients in fish diets informed through a multitude of rating systems operating at different scales and the need to continually evolve its meaning (e.g. life cycle models will soon be used as criteria). 


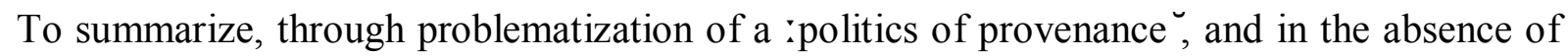
EU-wide public rules, private actors have created an ill-defined space of private government of EU-produced salmon whose :physical props `(Kauppi 2010, p28) are commercial contracts. One of the upshots of this autonomous private action is that it has empowered a range of actors through their assumption of authority to govern. This was particularly in evidence in reactions to the EU $\breve{s}$ SCFCAH decision to re-authorize PAPs in fishfeeds. It was stated clearly that, even if PAPs were considered sustainable according to EU instruments, as far as private standards were concerned, these did not recognize PAPs in this way. Dominant supermarkets in the UK-EU salmon market will not sell salmon fed on PAPs ${ }^{6}$. Private standards set in the name of European sustainability are thus trumping EU public policies.

\section{CONCLUSIONS: EU PUBLIC AND PRIVATE INTERDEPENDENCIES}

A central aim of this article has been to argue that research in EU studies should not consistently limit its analysis of European government to the action of the European Commission, the MSs and the EP, all be they acting in consultation with private actors. Rather, the scope of research should extend to considerations of voluntary private collective self-regulation where standards are being set in the name of Europe, even in the absence of EU public actors input. Accepting this argument requires acceptance too of a reconceptualized vision of the EU itself - not as an entity in Brussels, always consciously chosen, but as a space of action which connects :varied kinds of actors, involved in the construction of Europe to a greater or lesser extent, with formal roles or none, and at times without a clear consciousness of their engagement and its effects ${ }^{-}$(Carter et al. 2015 forthcoming).

\footnotetext{
${ }^{6}$ Dominant French supermarkets will not sell trout fed on PAPs either and this for the same reason, i.e. that business contracts negotiated collectively with the industry do not permit it.
} 
This decentred approach demands that analysis of EU regulation starts with how public and private actors are defining the space being governed (e.g., fishfeeds), rather than with some pre-determined image of what the EU is. To do this here, we have applied tools of :problematization $`$ and : instrumentation $`$ to the issue of sustainability in fishfeeds. We have studied the collective work of actors who are defining sustainability and setting instruments to regulate its contents. The importance of this conceptual shift is shown by revealing the complexity of the materiality of sustainability in EU fishfeeds in public and private realms compared. While EU public actors have not gone so far as to set sustainability criteria governing choices of raw materials and hence access to internal markets, some private actors in the EU salmon market have. Whereas following EU public regulation PAPs can be used in feeds in the name of European sustainability, the contents of private contracts for EU produced salmon also in the name of European sustainability will prevent their very usage.

The research thus points to a set of tensions between public and private action in the government of the EU which merit further consideration. More precisely, the case study offers new insights into the causes of enhanced private government. A central debate within the literature is whether the assuming of governing authority by the private sphere results from a de facto assignment of power to these actors through particular types of neo-liberal policies, or whether public actors are powerless in these processes. In this latter case, causes are rather located in responses to globalization and weaknesses of international trading organizations, such as the WTO, or the collective action of social movements which increases the number of stakeholders engaged in decision-making (Bartley and Child 2010; Bartley 2007; Fulponi 2006). Our case study suggests that searching for global accounts to explain shifting power relations can be a limiting exercise. Rather, through localizing and particularizing the inquiry on private self-regulation, we have shown that authority to govern is assigned through problematization. This will be specific in each case and demands detailed research. This is 
especially so given the continued sectorization of policies. For, not only are local relations between public and private actors likely to be structured within on-going policy logics and different mixes of de-regulation and intervention, but the European Commission is not a single actor with a single political programme. In fishfeeds, there was a complexity of reasons why Commission officials from different DGs sought to govern a politics of substitution and not a politics of provenance. These included beliefs in their limited role under WTO rules, beliefs in the bio-economy and lack of pressure from private actors, who were already governing.

Motives behind autonomous private self-regulation should also not be reduced to simplistic accounts of economic competiveness. As Bartley contends for forestry, it is tempting to view strategies of competitiveness as creating a need for new institutions [and this] simply becomes their explanation $`(2007, \mathrm{p} 298)$. But, and as he further argues, such a functionalist

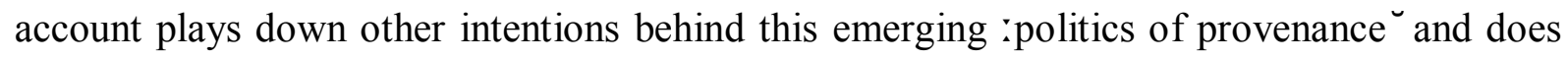
not explain the form of standards ultimately chosen (2007, p299). Certainly, engaging in a

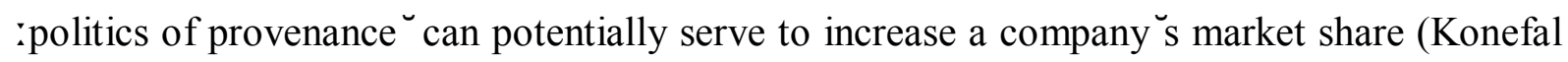
et al. 2005, p298). However, other motives were also in evidence, including legal and moral responsibility:

:we are living and breathing (sustainability) (it is) not just a bolt on... (but) embedded.... (and) fundamental ${ }^{\longleftarrow}$ (supermarket seafood policy officer).

Indeed, once private companies` narratives suggest they are acting because of beliefs in corporate social responsibility for the environment - a vision of their company having a territorial responsibility, akin to a public actor - then we are confronted with governing intentions beyond economic competitiveness. These merit closer, critical scrutiny, not least because of the potential consequences they have for democratic and transparent decision- 
making (Konefal et al. 2005), as well as for the value choices taken in the name of sustainable Europe and set in the standards. ${ }^{7}$

Finally, clearly the two worlds of the public/private are interdependent. Private standards on sustainable salmon rely on EU environmental rules to uphold production criteria contained within the standard and on public rules regulating feed fisheries. Commission officials in turn rely on private standard-setting to achieve public policy goals. Indeed, stated objectives for sustainable European aquaculture as set out in the 2009 strategy are that EU producers competitiveness should be achieved by

:position[ing] their products on the market as high value products based on their environmental performance, high health standards and traceability` (Commission 2009b, p4).

But, these goals cannot be delivered in the absence of private standard-setting. Indeed, producers can only pursue this strategy of competitiveness if they can demonstrate provenance and this requires their engagement in standardisation. EU public policy is therefore fundamentally dependent upon this private collective action, emphasizing once again the importance of European integration analysis which controls for these evolving interdependencies.

ACKNOWLEDGMENTS: The article draws on findings from a collective research project funded by the French Agence National de la Recherche under grant title `Le Gouvernement Européen de 1Tndustrie_(GEDI), 2009-2012. I would like to thank all those actors who agreed to be interviewed for the purposes of this research.

\section{REFERENCES}

\footnotetext{
${ }^{7}$ This piece has not critically addressed the contents of private standards set, see Carter, 2015 forthcoming.
} 
Bartley, T. (2007) Institutional emergence in an era of globalization: the rise of transnational private regulation of labour and environmental conditions, American Journal of Sociology 113(2), pp.297-351.

Bartley, T. and Child, C. (2010) Shaming the corporation: Globalization, reputation and the dynamics of anti-corporate movements . Available at:

http://citation.allacademic.com/meta/p_mla_apa_research_citation/1/8/4/7/3/pages 184737/p1847371.php

Bevir, M. (2011) Public Administration As Storytelling, Public Administration 89(1), pp.183-195.

Bevir, M. and Rhodes. R. (2010) The State as Cultural Practice (Oxford: Oxford University Press).

Bevir. M. Rhodes R. (2008) The differentiated polity as narrative, British Journal of Politics and International Relations 10, pp.729-734.

Beyers J. and Diericks G. (1998) The working groups of the Council of the European Union: supranational or intergovernmental negotiations?, Journal of Common Market Studies 36(3), pp.289-317.

Birch K., Levidow L. and Papaioannou T. (2010) Sustainable Capital? The Neoliberalization of Nature and Knowledge in the European :Knowledge-based Bio-economyॅ, Sustainability 2: pp.2898-2918.

Cafaggi, F. (2010) New Foundations of Transnational Private Regulation, EUI Working Paper, RSCAS, 2010/53.

Carter, C. (2015 forthcoming) De-politicizing Europe: Collective private action and sustainable Europe, in: C. Carter, and M. Lawn (eds) Governing Europe ss Spaces: European Union ReImagined, (Manchester: Manchester University Press). 
Carter, C. and Cazals, C. (2014) The EU `s government of aquaculture: completeness unwanted, in: B. Jullien, and A. Smith (eds) The EU`s Government of Industries: Markets, Institutions and Politics, (Abingdon: Routledge), 84-114.

Carter, C., Lawn, M. and Freeman, R. (2015 forthcoming) Introduction: governing Europe s spaces: European Union re-Imagined, in: C. Carter, and M. Lawn (eds) Governing Europe s Spaces: European Union Re-Imagined, (Manchester: Manchester University Press).

Carter, C. and Smith, A. (2008) Revitalizing Public Policy Approaches to the EU: :Territorial Institutionalism, `Fisheries and Wine, Journal of European Public Policy 15(2), pp.263-281.

Commission of the European Communities (2009a) Commission Staff Working Document accompanying the Communication from the Commission to the European Parliament and the Council Building A Sustainable Future For Aquaculture: A New Impetus For The Strategy For The Sustainable Development Of European Aquaculture, SEC(2009)453, Brussels.

Commission of the European Communities (2009b) Communication from the Commission to the European Parliament and the Council Building A Sustainable Future For Aquaculture: A New Impetus For The Strategy For The Sustainable Development Of European Aquaculture, $\operatorname{COM}(2009) 162$ final, Brussels.

Commission of the European Communities (2002) Final communication From The Commission To The Council And the European Parliament a Strategy For The Sustainable Development Of European aquaculture Commission Of The European Communities, $\operatorname{COM}(2002) 511$ : Brussels.

Crawford, M. (2010) The importance of long chain omega-3 fatty acids for human health, Paper presentation at IG-CCBSD conference :Can A Growing Aquaculture Industry Continue To 
Use Fishmeal And Fish Oil In Feeds And Remain Sustainable?־, European Parliament, Brussels, 3 March 2010.

De Maillard, J. (2001) La Commission, le vin et la réforme, Politique Europénne 5, pp.7086.

Djama, M., Fouilleux, E. and Vagneron, I. (2011) Standard-setting, certifying and benchmarking: A governmentality approach to sustainable standards in the agro-food sector, in: S. Ponte, P. Gibbon, and J. Vestergaard, (eds), Governing through standards: Origins, Drivers and Limitations, pp.184-209 (Basingstoke: Palgrave MacMillan).

Favell, A. and Guiraudon, V. (2009) The Sociology of the EU: an Agenda, EU Politics 10, pp.550576.

Fligstein, N. (2008) Euroclash: the EU, European Identity and the Future of Europe (Oxford: Oxford University Press).

Fulponi, L. (2006) Private voluntary standards in the food system: The perspective of major food retailers in OECD countries, Food Policy 31, pp. $1^{-} 13$.

Gilbert, C. and Henry, E. (2012) Defining social problems: tensions between discreet compromise and publicity, Revue française de sociologie (English), 1(53), pp.31-54.

Ginsberg, R. (2007) Demystifying the European Union: The enduring logic of European integration (Plymouth: Rowman and Littlefield).

Greenpeace (2005) A Recipe For Disaster: Supermarkets` Insatiable Appetite For Seafood (London: Greenpeace).

Greenpeace (2006) A Recipe for Change: Supermarkets Repond to the Challenge of Sourcing Responsible Seafood (London: Greenpeace). 
Havinga, T. (2006) Private regulation of food safety by supermarkets, Law and Policy 28(4), pp.515533.

Hay, C. (2007) Why we hate politics (Cambridge: PolityPress).

Hites, R., Foran, J., Carpenter, D., Hamilton, M., Knuth, B. And Schwager, S. (2004) Global Assessment of Organic Contaminants in Farmed Salmon, Science 303, pp.226-229.

Hughes, A., Wrigley, N. and Buttle, M. (2008) Global production networks, ethical campaigning, and the embeddedness of responsible governance, Journal of Economic Geography 8, pp.345367.

Huntington, T.C. (2004) Feeding the Fish: Sustainable Fish Feed and Scottish Aquaculture. Report to the Joint Marine Programme Scottish Wildlife Trust and WWF Scotland and RSPB Scotland.

Jeffery, C. (2000) Sub-national mobilization and European integration, Journal of Common Market Studies 38(1), pp.1²3.

Jullien, B and Smith, A. (eds) (2014) The EU`s Government of Industries: Markets, Institutions and Politics (Abingdon: Routledge).

Kauppi, N. (2010), The Political Ontology of European Integration, Comparative European Politics 8(1), pp.19-36.

Konefal, J Mascarenhas, M and Hatanaka, M. (2005) Governance in the global agro-food system: Backlighting the role of transnational supermarket chains, Agriculture and Human Values 22, pp. $291^{-} 302$.

Lawn, M. (2006) Soft governance and the learning spaces of Europe, Comparative European Politics 4, pp. $272^{-} 288$. 
Lascoumes P, Le Galès, P. (2007) Introduction: Understanding Public Policy through Its Instruments:

From the Nature of Instruments to the Sociology of Public Policy Instrumentation, Governance: An International Journal of Policy, Administration, and Institutions 20, pp.1-21.

LeGalès, P and Scott, A. (2008) Une Révolution Bureaucratique Britannique? Autonomie sans contrôle ou « freer markets, more rules, Revue française de sociologie 49(2), pp.301-330.

Lelieveldt, H. and Princen, S. (2011) The politics of the EU (Cambridge: CUP).

Marks, G. and McAdam, D. (1996) Social movements and the changing structure of political opportunity in the EU in G. Marks et al. (eds), Governance in the European Union, pp. $95^{-}$ 120 (London: Sage).

Mangenot, M. and Rowell, J. (eds) (2010) A Political Sociology of the EU: Reassessing Constructivism (Manchester: Manchester University Press).

Mauriac, L 17/02/2013 à 17h50 Farines pour poissons et viande de cheval, même logique pour Batho, Rue 89

http://www.rue89.com/rue89-planete/2013/02/17/farines-pour-poissons-et-viande-de-cheval-memelogique-pour-batho-239712

Milana, G. (2010) Report on a New Impetus for the Strategy for the Sustainable Development of European Aquaculture, A7-0150/2010, European Parliament, 7.5.2010.

Nautilus (2003) Seafeeds: Sustainable environmental aquaculture feeds. Report of conference held 89 April, Stirling Management Centre, Edinburgh: Nautilus Consultants and Institute of Aquaculture, Stirling.

Nugent, N. (2010) The government and politics of the European Union (Basingstoke: Palgrave Macmillan). 
Peterson J. (1995) Policy networks and European union policy making: A reply to Kassim, West European Politics 18, pp.389-407.

Ponte, S. Gibbon, P. and Vestergaard, J. (eds) (2011) Governing through standards: Origins, Drivers and Limitations (Basingstoke: Palgrave MacMillan).

Richardson, J. (ed.) (1996) European Union: Power and Policy-Making (London: Routledge).

Robert, C. (2010) Who are the European experts? Profiles, trajectories and expert :careers ` of the European Commission, French Politics 8(3), pp.248-274.

Rochefort, D. and Cobb, R. (1994) The Politics of Problem Definition (Lawrence, KS:University Press of Kansas).

Rumford, C. (2002) The European Union: A Political Sociology (London: Blackwell Publishing).

Scicluna N. (2012) When Failure isn't Failure: European Union Constitutionalism after the Lisbon Treaty, Journal of Common Market Studies 50, pp.441-456.

Smith, A. (2013) Policy-making within the European Commission: Problematization, Instrumentation and Legitimation, Journal of European Integration, http://www.tandfonline.com/doi/full/10.1080/07036337.2013.809344

Smith A. (2010) 2nd edition Le gouvernement de ľUnion européenne. Une sociologie politique (Paris: LGDJ).

Svea, L. (2010) A speaking cure for conflicts: problematization, discourse stimulation and the ongoing of scientific progress, Critical Policy Studies 4(3), pp.278-296.

Young, A. and Peterson, J. (2006) Introduction: The EU and the New Trade Politics, Journal of European Public Policy, 13(6), pp.795-814. 